\title{
The Clinical Efficacy of Silicone Stents for Endoscopic Dacryocystorhinostomy: A Meta-Analysis
}

\author{
Do Hyun $\mathrm{Kim}^{1}$ · Seon Ik Kim · Ho Jun $\mathrm{Jin}^{2}$ • Subin $\mathrm{Kim}^{2}$ · Se Hwan Hwang ${ }^{2}$ \\ ${ }^{1}$ Department of Otolaryngology-Head and Neck Surgery, Seoul St. Mary's Hospital, College of Medicine, The Catholic University of Korea, Seoul; \\ ${ }^{2}$ Department of Otolaryngology-Head and Neck Surgery, Bucheon St. Mary's Hospital, College of Medicine, The Catholic University of Korea,
}

Bucheon, Korea

\begin{abstract}
We evaluated the effect of silicone stent use during endoscopic dacryocystorhinostomy on postoperative morbidities in comparison with versus without a silicone stent. Two authors independently searched six databases (PubMed, Embase, Scopus, the Web of Science, the Cochrane library, and Google Scholar) from inception of article collection to July 2017. The analysis included prospective randomized studies that compared intraoperative silicone stent insertion (silicone group) with no application of a silicone stent (control group), in which the outcomes of interest were success rate (lacrimal passage patent check with syringing, symptom relief, or endoscopic confirmation of fluorescein dye from the opening of Hasner's valve) and morbidities (e.g., postoperative bleeding, rhinostomy closure, granulation tissue, synechia, and eyelid problems) after certain follow-up periods (over 10 weeks). Nine studies involving a total of 587 participants were included. Functional success rates tended to be higher in the silicone group than in the control, but there was no statistically significant difference in success rates (odds ratio, $1.45 ; 95 \%$ confidence interval, 0.77 to 2.73 ). According to the surgical type such as mucosal removal and mucosal flap surgery, the results from types didn't demonstrate any significant effect, but the mucosal flap technique seemed to be more beneficial. Regarding postoperative morbidities, although the outcomes of the groups did not present any statistically significant difference, eyelid problems and postoperative bleeding tended to occur more frequently in the silicone group, but rhinostomy closure tended to occur more frequently in the control group. Success and morbidity rates showed no difference between the silicone stent group and control group in the meta-analysis. However, additional analyses revealed that the success rate of endonasal dacryocystorhinostomy using silicone intubation with mucosal flap has shown an improving trend, and morbidities such as granulation and synechia showed decreasing trends compared with the group without silicone intubation.
\end{abstract}

Keywords. Dacryocystorhinostomy; Silicones; Stents; Nasolacrimal Duct Obstruction; Meta-Analysis

\section{INTRODUCTION}

Dacryocystorhinostomy (DCR) is performed to secure drainage passage between the lacrimal sac and nasal cavity for treating nasolacrimal duct obstruction (NLDO) or stenosis [1]. Since DCR using an external approach was first reported in 1904 by

\footnotetext{
- Received December 18, 2017

Revised January 2, 2018

Accepted January 10, 2018

- Corresponding author: Se Hwan Hwang

Department of Otolaryngology-Head and Neck Surgery, Bucheon St. Mary's Hospital, College of Medicine, The Catholic University of Korea, 327 Sosa-ro, Wonmi-gu, Bucheon 14647, Korea

Tel: +82-32-340-7044, Fax: +82-32-340-2674

E-mail: yellobird@catholic.ac.kr
}

Toti, external (Ex)-DCR has been considered as representative treatment for NLDO [2].

However, the introduction of endoscopes with high-resolution led to the performance of endoscopic endonasal (En)-DCR. Many clinicians have advocated this surgical procedure for its several advantages, including no facial scarring, minimal blood loss, preservation of the medial canthal ligament, short operative time, and shortened hospitalization stay compared with Ex-DCR, as well as simultaneous correction of the most common causes of En-DCR failure, such as adhesions, deviated nasal septum, hypertrophic turbinates, or infected ethmoid sinuses [3]. En-DCR is now suggested as an alternative to Ex-DCR $[4,5]$. Thus, with the increasing popularity of En-DCR, the complications associated with En-DCR have received attention.

Copyright @ 2018 by Korean Society of Otorhinolaryngology-Head and Neck Surgery.

This is an open-access article distributed under the terms of the Creative Commons Attribution Non-Commercial License (http://creativecommons.org/licenses/by-nc/4.0)

which permits unrestricted non-commercial use, distribution, and reproduction in any medium, provided the original work is properly cited. 
However, the evidence in the existing report is not sufficient to conclude the role of silicone stenting during En-DCR fully [1]. Considering that the popularity of En-DCR for treating NLDO patients will continue for the time being, it is important for surgeons to follow effective surgical practices to decrease postoperative morbidities. This review aimed to assess the efficacy and complication of silicone stents to improve NLDO patient experiences with En-DCR.

\section{MATERIALS AND METHODS}

\section{Literature search strategy}

A search of clinical studies was performed in PubMed, Embase, Scopus, the Web of Science, the Cochrane library, and Google Scholar up to a cutoff date of July 2017. The terms for searching followed: "endoscopy," "dacryocystorhinostomy," "silicone intubation," "stent," "nasolacrimal duct obstruction," "dacryocystitis," "success," and "morbidity." Only literatures published in English were selected. Not to miss any relevant reports, the reference lists were checked within the identified studies.

Two literature reviewers independently screened titles and abstracts for all candidate studies, and studies unrelated to intraoperative insertion of silicone stents during En-DCR were excluded. The entire text of a potentially relevant study was reviewed if inclusion of that study could not be decided based on the abstract solely.

\section{Selection criteria}

Randomized controlled clinical trials that satisfy the following criteria were the objects of review: comparison of the success rates (subjective or objective assessments) and postoperative morbidities of patients received En-DCR with versus without a silicone stent. Studies were excluded if the patients had undergoing previous lacrimal surgery, had a history of trauma to the nasal or ocular region, or had experienced presaccal obstruction and the paranasal sinus malignancies, or if it was a duplicate report. Additionally, reports were not included if the clinical outcomes were reported without clear quantifiable data, or if the calculation results disagree with the appropriate data from the

\section{H I G H L I G H T S}

- The success and postoperative morbidity rates showed no differences between the silicone stent and control groups.

- The success rate of endoscopic endonasal dacryocystorhinostomy using silicone intubation has shown an improving trend recently.

- The rates of morbidities such as granulation and synechia have shown decreasing trends in the endoscopic endonasal dacryocystorhinostomy with silicone cases. published reports. The searching strategy utilized for verifying the appropriate studies for the meta-analysis is summarized in Fig. 1.

\section{Data extraction and risk of bias assessment}

Data extraction was performed with standardized forms and independently checked by two reviewers (DHK, SHH). Outcome results of the analysis included success rate [2,6-12] (evident lacrimal drainage on syringing, symptom relief, or nasal endoscopic identification of fluorescein dye in the DCR opening [13]) and postoperative morbidities (postoperative bleeding $[4,6,11$, $12]$, rhinostomy closure [5,9], granulation tissue [6,12], synechia $[9,10,12]$, and eyelid problem such as eyelid swelling $[2,9])$. These outcomes in patients undergoing En-DCR with silicone stenting were compared with those of a control group (defined as patients undergoing En-DCR without silicone stenting) after certain follow-up periods (over 10 weeks).

We extracted data about the number of En-DCR patients, the rates of success, postoperative bleeding, rhinostomy closure, granulation tissue, synechia, and eyelid problems, and $P$-values from comparisons between the silicone and control groups. The risk of bias in each literature was analyzed using "Risk of Bias" tool in the Cochrane.

\section{Statistical analysis and outcome measurements}

The statistical software R ver. 3.3.0 (The R Foundation, Vienna, Austria) was used to perform a meta-analysis of the selected studies. The "metafor" package for the effective measurements was utilized as the library in the R software. Odds ratios (ORs) were calculated based on an outcome incidence analysis. An OR is a measure of association between a silicon stent insertion and outcomes (success or postoperative morbidities). The OR represents the odds that an outcome will occur given a silicon stent insertion, compared to the odds of the outcome occurring in the absence of that treatment. In the meaning of values of, the value of OR is the same as " 1 ," which means that treatment does not affect odds of outcome. If the value is larger than 1, the treatment could be associated with higher odds of outcome. By contrast, if the value is smaller than 1 , the treatment could be associated with lower odds of outcome. Heterogeneity was calculated with the $\mathrm{I}^{2}$ test, which describes the rate of variation across studies because of heterogeneity rather than probabilistic chance. The measure ranged from 0 (no heterogeneity) to 100 (maximum heterogeneity). All results were reported with a $95 \%$ confidence intervals (CI), and all $P$-values were two-tailed. When significant heterogeneity among outcomes was found (defined as $\mathrm{I}^{2}>50$ ), the random-effects model was used. An Egger's test and Begg's funnel plot were used to assess the potential publication bias. According to publication bias, Duval and Tweedie's trim and fill method was used to correct for missing studies and the overall effect size. Additionally, to estimate the effect of individual study in the overall meta-analysis results, sensitivity anal- 


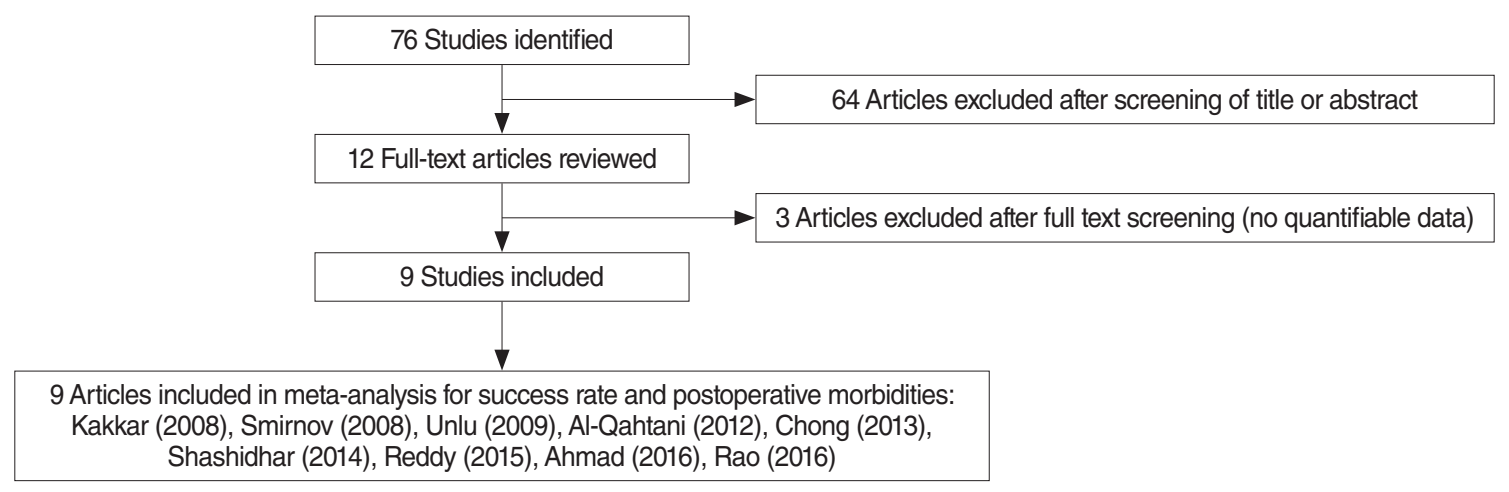

Fig. 1. Flowchart of the study selection.

Table 1. Summary of studies included in the meta-analysis

\begin{tabular}{|c|c|c|c|c|}
\hline $\begin{array}{l}\text { First author (year)/operation } \\
\text { type }\end{array}$ & $\begin{array}{l}\text { No. of patients in each } \\
\text { group }\end{array}$ & Level of evidence & Surgical procedure/measure analyzed & $\begin{array}{l}\text { Judgment of } \\
\text { risk of bias }\end{array}$ \\
\hline $\begin{array}{l}\text { Kakkar (2008) [6]/local } \\
\text { anesthesia }\end{array}$ & Silicon (20) vs. control (20) & $\begin{array}{l}\text { Level I (randomized con- } \\
\text { trolled prospective study) }\end{array}$ & $\begin{array}{l}\text { Removal lacrimal sac mucosa/success rate, } \\
\text { postoperative morbidities (postoperative } \\
\text { bleeding and rhinostomy closure) }\end{array}$ & Unclear \\
\hline $\begin{array}{l}\text { Smirnov (2008) [4]/general } \\
\text { anesthesia }\end{array}$ & Silicon (23) vs. control (23) & $\begin{array}{l}\text { Level I (randomized con- } \\
\text { trolled prospective study) }\end{array}$ & $\begin{array}{l}\text { Removal lacrimal sac mucosa/success rate, } \\
\text { postoperative morbidities (postoperative } \\
\text { bleeding) }\end{array}$ & Unclear \\
\hline $\begin{array}{l}\text { Unlu (2009) [2]/general } \\
\text { anesthesia }\end{array}$ & Silicon (19) vs. control (19) & $\begin{array}{l}\text { Level I (randomized con- } \\
\text { trolled prospective study) }\end{array}$ & $\begin{array}{l}\text { Removal lacrimal sac mucosa/success rate, } \\
\text { postoperative morbidities (eyelid problem, } \\
\text { granulation tissue) }\end{array}$ & High \\
\hline $\begin{array}{l}\text { Al-Qahtani (2012) [7]/general } \\
\text { anesthesia }\end{array}$ & Silicon (92) vs. control (81) & $\begin{array}{l}\text { Level I (randomized con- } \\
\text { trolled prospective study) }\end{array}$ & Flap surgery/success rate & High \\
\hline $\begin{array}{l}\text { Chong (2013) [8]/general or } \\
\text { local anesthesia }\end{array}$ & Silicon (63) vs. control (65) & $\begin{array}{l}\text { Level I (randomized con- } \\
\text { trolled prospective study) }\end{array}$ & $\begin{array}{l}\text { Flap surgery/success rate, postoperative } \\
\text { morbidities (granulation tissue) }\end{array}$ & low \\
\hline $\begin{array}{l}\text { Shashidhar (2014) [9]/ } \\
\text { uncommented }\end{array}$ & Silicon (32) vs. control (30) & $\begin{array}{l}\text { Level I (randomized con- } \\
\text { trolled prospective study) }\end{array}$ & $\begin{array}{l}\text { Not specified/success rate, postoperative } \\
\text { morbidities (eyelid problem, granulation tissue, } \\
\text { and synechia) }\end{array}$ & High \\
\hline $\begin{array}{l}\text { Reddy (2015) [10]/local } \\
\text { anesthesia }\end{array}$ & Silicon (10) vs. control (10) & $\begin{array}{l}\text { Level I (randomized con- } \\
\text { trolled prospective study) }\end{array}$ & $\begin{array}{l}\text { Removal lacrimal sac mucosa/success rate, } \\
\text { postoperative morbidities (synechia) }\end{array}$ & High \\
\hline $\begin{array}{l}\text { Ahmad (2016) [11]/local } \\
\text { anesthesia }\end{array}$ & Silicon (15) vs. control (15) & $\begin{array}{l}\text { Level I (randomized con- } \\
\text { trolled prospective study) }\end{array}$ & $\begin{array}{l}\text { Flap surgery/success rate, postoperative } \\
\text { morbidities (postoperative bleeding) }\end{array}$ & Unclear \\
\hline $\begin{array}{l}\text { Rao (2016) [12]/local } \\
\text { anesthesia }\end{array}$ & Silicon (20) vs. control (20) & $\begin{array}{l}\text { Level I (randomized con- } \\
\text { trolled prospective study) }\end{array}$ & $\begin{array}{l}\text { Removal lacrimal sac mucosa/success rate, } \\
\text { postoperative morbidities (postoperative } \\
\text { bleeding, rhinostomy closure, and synechia) }\end{array}$ & High \\
\hline
\end{tabular}

yses were conducted. This was performed by repeating the metaanalyses while omitting a different study each time.

\section{RESULTS}

In total, nine studies involving 587 patients were included in the meta-analysis. Study characteristics and the bias assessment results are described in Table 1.

\section{Comparison of the success rate between the silicone stent and control groups}

The results of nine studies with related to success rate between silicone stent and control groups are summarized in Fig. 2. There was no significant heterogeneity among studies $\left(\mathrm{I}^{2}=0 \%\right)$. Although the use of silicone stents showed a tendency to increase the success rate compared with the control group (OR, 1.45; 95\% confidence interval $[\mathrm{CI}], 0.77$ to $2.73 ; P=0.244)$, there was no statistically significant improvement in outcome. Egger's test $(P=0.488)$ suggested no publication bias source in these studies. No significant difference between observed and adjusted values appeared using the Duval and Tweedie's trim and fill method. These test results show that the selected studies were not biased.

In this measurement, there were two different types of surgery such as mucosal removal and mucosal flap surgery, which could show the surgical results differently. Therefore, we performed the subgroup analysis according to the surgical type. The results from two different surgical types didn't demonstrate any signifi- 


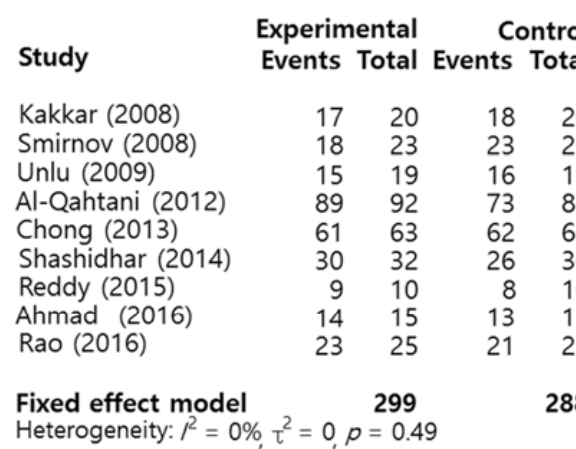

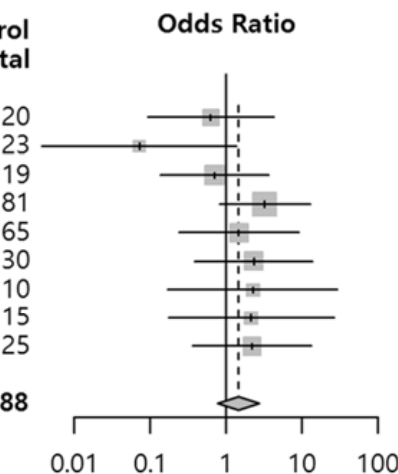

OR $\quad 95 \%-\mathrm{Cl}$ Weight

$0.63[0.09 ; 4.24] \quad 10.9 \%$

$0.07[0.00 ; 1.38] \quad 4.5 \%$

$0.70[0.13 ; 3.68] 14.5 \%$

$3.25[0.83 ; 12.70] \quad 21.3 \%$

$1.48 \quad[0.24 ; 9.14] \quad 11.9 \%$

$2.31[0.39 ; 13.64] \quad 12.5 \%$

$2.25[0.17 ; 29.77] \quad 5.9 \%$

$2.15[0.17 ; 26.67] \quad 6.2 \%$

$2.19[0.36 ; 13.22] \quad 12.2 \%$

$1.45[0.77 ; 2.73] 100.0 \%$

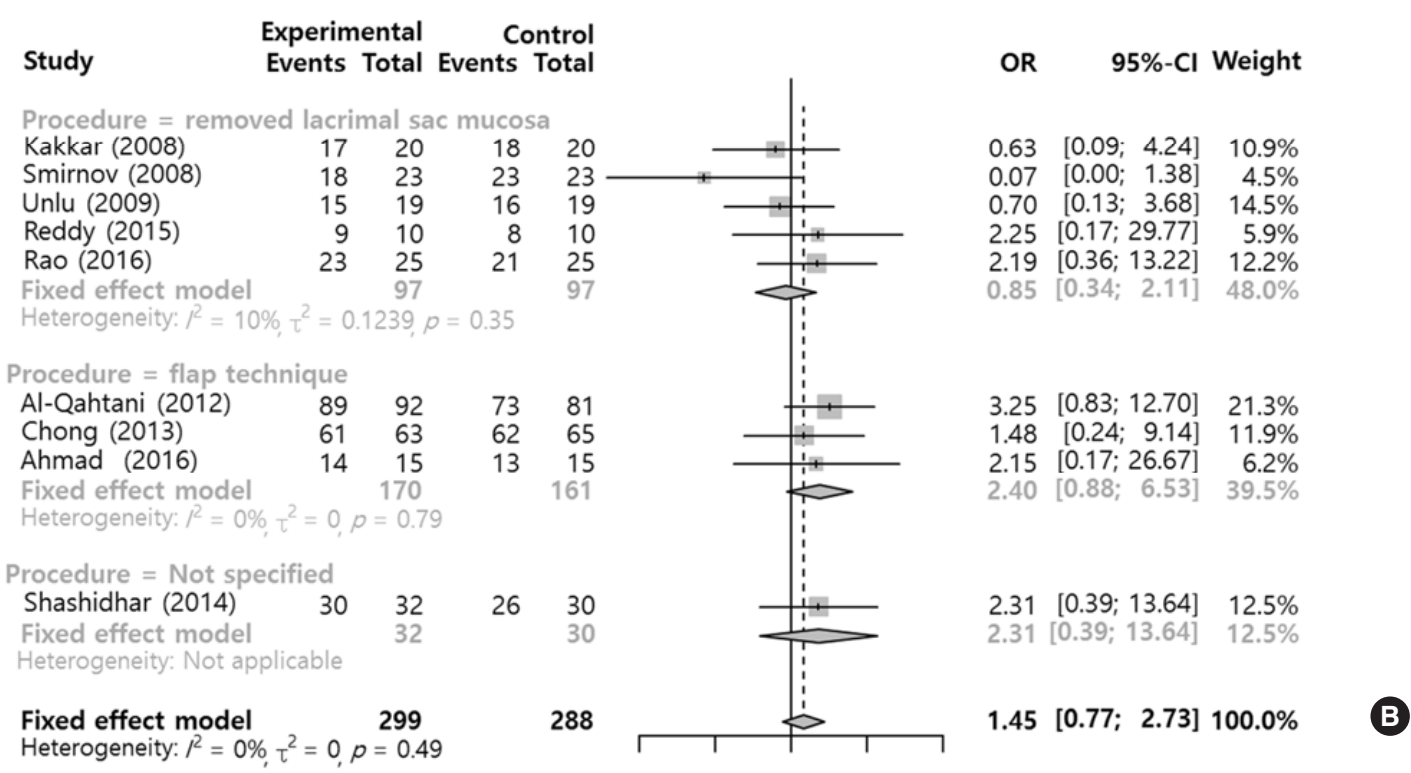

Fig. 2. Comparison of success rates between the silicone stent and control groups. Odds ratios (ORs) for success rate (A) and subgroups analysis according to the surgical type such as mucosal removal and flap surgery (B). Total, number of participants per group; $\mathrm{Cl}$, confidence interval.

cant effect, but the mucosal sparing surgery (OR, 2.40; 95\% CI, 0.88 to 6.53 ) and flap technique seemed to be more beneficially effective than mucosal removal surgery (OR, $0.85 ; 95 \% \mathrm{CI}, 0.34$ to 2.11) when it came to the surgical success (Fig. 2). In the sensitivity analysis, there was no significant change of results (Fig. 3).

\section{Comparison of postoperative morbidities between the silicone stent and control groups}

The results of two to four studies with respect to postoperative morbidities in the silicone tube versus control groups are included. There was no significant inter-study heterogeneity $\left(\mathrm{I}^{2}=0 \%\right)$ or publication bias $(P$-value of Egger's test $<0.05)$ among these outcomes. No difference in postoperative bleeding (OR, 2.53; $95 \%$ CI, 0.80 to $8.03 ; P=0.107$ ), eyelid problems (OR, 3.10; $95 \%$ CI, 0.69 to $14.00 ; P=0.114$ ), rhinostomy closure (OR, $0.18 ; 95 \%$ CI, 0.02 to $1.63 ; P=0.127)$, granulation tissue (OR, $1.07 ; 95 \%$ CI, 0.57 to $2.01 ; P=0.838$ ), or synechia (OR, $0.64 ; 95 \% \mathrm{CI}, 0.17$ to $2.48 ; P=0.521$ ) was evident between the two groups (Fig. 4).

\section{Study \\ Omitting Kakkar (2008) Omitting Smirnov (2008) Omitting Unlu (2009) Omitting Al-Qahtani (2012) Omitting Chong (2013) Omitting Shashidhar (2014) Omitting Reddy (2015) Omitting Ahmad (2016) Omitting Rao (2016)}

Fixed effect model

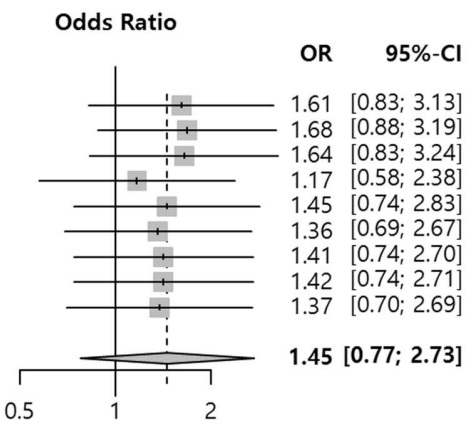

Fig. 3. Sensitivity analysis of success rates between the silicone stent and control groups. OR, odds ratio; $\mathrm{Cl}$, confidence interval.

However, silicone stenting showed a tendency to increase the rates of postoperative bleeding and eyelid problems compared with the control group. Additionally, silicone stenting tended to delay rhinostomy closure compared with the control group. The 


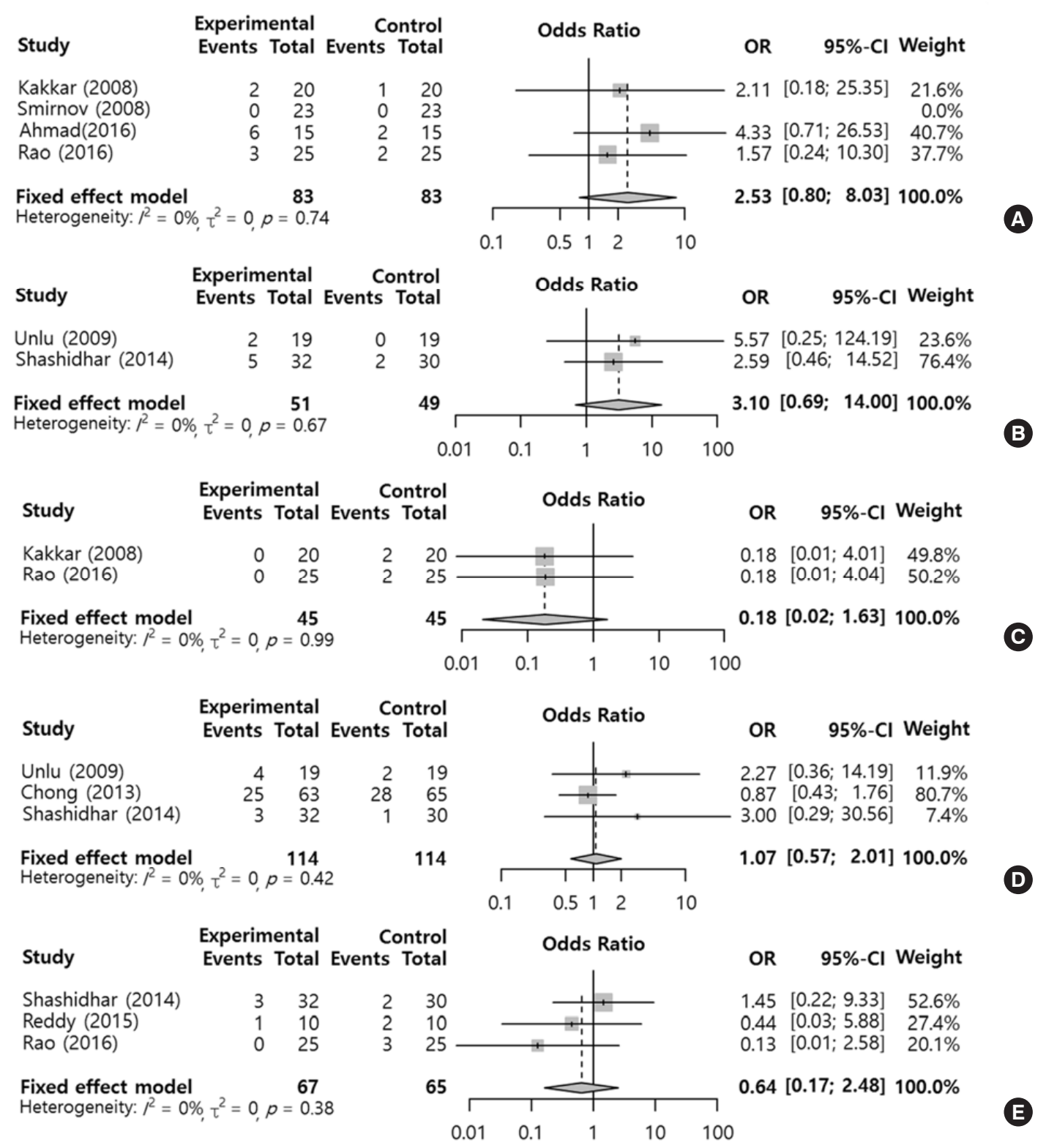

Fig. 4. Comparison of postoperative morbidity rates between the silicone stent and control groups. Odds ratios (ORs) for the incidence of postoperative bleeding (A), eyelid problems (B), rhinostomy closure (C), granulation tissue (D), and synechia (E). Total, number of participants per group; $\mathrm{Cl}$, confidence interval.

subgroup analysis according to the surgical type could not be performed, because there were a small number of the included studies in the individual results.

\section{Sensitivity analysis}

Sensitivity analyses were conducted to assess the difference between the pooled estimates of success rate and postoperative morbidities by repeating the analyses while omitting a different study each time. The final results were consistent with those above.

\section{DISCUSSION}

The surgical success was defined with either patent lacrimal passage on syringing, symptom improvement, or fluorescein dye in the DCR opening on nasal endoscopy [13]. On the other hand, surgical failure was defined as recurrence or persistence of symptoms during the follow-up period $[10,13]$. Surgical failure was closely related to complication such as rhinostomy closure [14].

In consideration of the maintenance of rhinostomy site, many surgeons have thought that placing stents or tube simultaneously during endoscopic DCR would be the gold standard proce- 
dure and has been performed accordingly [6]. Among the various stent materials such as silicone, polyurethane, Prolene stents, silicone has been used most commonly due to a stable and nonantigenic material [15]. However, unlike common belief that silicone tube insertion increases the postoperative patency rate by maintaining opening of the ostium $[9,12,16]$, recent studies demonstrated that silicone stent itself would be a reason for surgical failure as well as complications such as punctual erosion and splitting of canaliculi $[2,6,17,18]$.

In a previous meta-analysis regarding silicone tube intubation in DCR [13], they included all EX-DCR and EN-DCR (included laser-assisted technique) method in the study. As a result, there was no clear evidence that intubation in DCR was superior to nonintubation. However, this meta-analysis included not only randomized controlled tests but also retrospective cohort studies. Therefore, it was difficult to define clear conclusion including overall high risk of bias studies. Recently, several randomized controlled studies regarding EN-DCR were consistently reported. It is possible that analysis focused on randomized controlled studies about EN-DCR consequently. Therefore, we intended to combine the results regarding the debatable issue and show the summated effect of silicone stent insertion in the EN-DCR on the surgical success and complications through the metanalysis. In general, rhinostomy closure, granulation, and synechia are known to be closely associated with En-DCR failure. These complications are crucial factors which can affect surgical outcome. Among these complications, only rhinostomy closure tended to decrease relatively in the silicone stent group compared with control group. However, there was no statistical significance between two groups, which could explain the effect of silicone stent on the surgical success rate.

Nevertheless, from the surgical methods point of view, there were two distinctive methods to treat rhinostomy site in the nasal mucosa after lacrimal bone removal. Mucosal flap technique was usually performed with incision of the lacrimal sac and marsupialization with anterior and posterior flaps [8]. On the other hand, removal of lacrimal sac mucosa technique could be conducted with simple removal of the medial wall of the lacrimal sac. The former seems to cause the less injury of mucosa and the latter seems to result in more severe injury and expose the bare bone, which could show heterogeneous results. Therefore, we conducted the subgroups analysis according the surgical methods. As a result, mucosal flap technique seemed to be more beneficially effective on the success rate of EN-DCR than mucosal removal surgery although there were no significant difference owing to few reported randomized controlled prospective studies. This outcome might be the result of relatively lesser mucosal margin injury in the cases of mucosal flap technique. Further studies needed to be enrolled to reach the conclusion and explain the results.

Eyelid problems such as swelling and postoperative bleeding tended to decrease relatively in the silicone stent group com- pared with control group despite statistical insignificance. These complications usually occur due to the trauma during probe tubing procedure, but they occurred temporarily for the most part and recovered after conservative care, having little effect on the surgical success rate. However, these problems could cause the dissatisfaction of both patients and surgeons. Previously, Unlu et al. [5] recommended silicone intubation for all En-DCR procedures, since the surgical ostium created during En-DCR heals with granulation, as creating an epithelium-lined fistula is technically impossible. This suggestion could be contradicted by our results regarding the success rate and surgical complications. Rather, other factors such as condition of mucosa, size of rhinostomy, and presence of infection would be essential factors in success of En-DCR [15]. Consequently, the use of silicone tubes to maintain the canal and careful endoscopic manipulation needs to be performed on the basis of the patients' conditions and surgeons' experiences, which might reduce complications and improve surgical success rates in En-DCR.

This study has several limitations. The meta-analysis included only nine randomized, controlled, prospective studies. Thus, the sample size was small. The timing of tube removal, follow-up interval, and measurement indices were not fully consistent across the studies. These factors may have caused bias. Considering these limitations, a large-sample, randomized, controlled clinical study should be performed to provide further evidence on the efficacy of silicone intubation in En-DCR. Additionally, this analysis is performed based on the statistical measurements of the figure in the articles. So, external factors such as patient characteristics or demographic factors, surgeon skill, postoperative care, facility capacity could not be reflected in the analysis, which could be the inevitable limitation.

In conclusion, the success and postoperative morbidity rates showed no differences between the silicone stent and control groups in this meta-analysis. However, an additional meta-analysis revealed that the success rate of En-DCR using silicone intubation with mucosal flap has shown an improving trend. Consequently, surgeons need to perform the silicone intubation during En-DCR with simultaneously mucosal flap with careful consideration.

\section{CONFLICT OF INTEREST}

No potential conflict of interest relevant to this article was reported.

\section{ACKNOWLEDGMENTS}

This work was supported by the National Research Foundation of Korea (NRF) grant funded by the Korea Government (MSIP, MSIT) (2017R1D1A1B03027903, 2018M3A9E8020856), the 
Korea Health Industry Development Institute funded by the Ministry of Health and Welfare (HI14C3228, HI15C0133), Institute for Information \& Communications Technology Promotion (IITP) grant funded by the Korea Government (MSIP) (No. 2017-0-00953), the Institute of Clinical Medicine Research of Bucheon St. Mary's Hospital Research Fund (2018), and a grant of the ENT Fund of the Catholic University of Korea made in the program year 2017 and 2018, Republic of Korea.

\section{REFERENCES}

1. Xie C, Zhang L, Liu Y, Ma H, Li S. Comparing the success rate of dacryocystorhinostomy with and without silicone intubation: a trial sequential analysis of randomized control trials. Sci Rep. 2017 May; 7(1):1936.

2. Unlu HH, Gunhan K, Baser EF, Songu M. Long-term results in endoscopic dacryocystorhinostomy: is intubation really required? Otolaryngol Head Neck Surg. 2009 Apr;140(4):589-95.

3. Mohamad SH, Khan I, Shakeel M, Nandapalan V. Long-term results of endonasal dacryocystorhinostomy with and without stenting. Ann R Coll Surg Engl. 2013 Apr;95(3):196-9.

4. Smirnov G, Tuomilehto H, Terasvirta M, Nuutinen J, Seppa J. Silicone tubing is not necessary after primary endoscopic dacryocystorhinostomy: a prospective randomized study. Am J Rhinol. 2008 Mar-Apr;22(2):214-7.

5. Unlu HH, Toprak B, Aslan A, Guler C. Comparison of surgical outcomes in primary endoscopic dacryocystorhinostomy with and without silicone intubation. Ann Otol Rhinol Laryngol. 2002 Aug;111(8): 704-9.

6. KakkarV, Chugh J, Sachdeva S, Sharma N, Ramesh. Endoscopic dacryocystorhinostomy with and without silicone stent: a comparative study. Internet J Otolaryngol. 2008;9(1).
7. Al-Qahtani AS. Primary endoscopic dacryocystorhinostomy with or without silicone tubing: a prospective randomized study. Am J Rhinol Allergy. 2012 Jul-Aug;26(4):332-4.

8. Chong KK, Lai FH, Ho M, Luk A, Wong BW, Young A. Randomized trial on silicone intubation in endoscopic mechanical dacryocystorhinostomy (SEND) for primary nasolacrimal duct obstruction. Ophthalmology. 2013 Oct;120(10):2139-45.

9. Shashidhar K, Nagalotimath U, Dixit D. Endoscopic dacryocystorhinostomy with and without silicone stenting: a comparative study. Al Ameen J Med Sci. 2014 Jul;7(3):244-7.

10. Reddy YJ, Reddy YM, Kiran M, Reddy YG, Kumar SP. A comparative study of outcomes of dacryocystorhinostomy with and without silicone stenting. IOSR J Dent Med Sci. 2015 Jul;14(7):82-5.

11. Ahmad S, Pant B. Role of silicone stenting in endoscopic dacryocystorhinostomy: a comparative study. Int J Adv Integr Med Sci. 2016 Jan;1(1):4-6.

12. Rao SV, Rajshekar MM. Dacryocystorhinostomy stent insertion in initial endoscopic dacryocystorhinostomy. Clin Rhinol Int J. 2016 Sep;9(3):120-4.

13. Feng YF, Cai JQ, Zhang JY, Han XH.A meta-analysis of primary dacryocystorhinostomy with and without silicone intubation. Can J Ophthalmol. 2011 Dec;46(6):521-7.

14. Selig YK, Biesman BS, Rebeiz EE. Topical application of mitomycinC in endoscopic dacryocystorhinostomy. Am J Rhinol. 2000 MayJun;14(3):205-7.

15. Shah H, Sharma S, Suri N, Patel A. Comparison of surgical outcome in endoscopic dacryocystorhinostomy with and without silicon stent placement. Natl J Med Res. 2013 Jan-Mar;3(1):34-7.

16. Mantynen J, Yoshitsugu M, Rautiainen M. Results of dacryocystorhinostomy in 96 patients. Acta Otolaryngol Suppl. 1997;529:187-9.

17. Allen K, Berlin AJ. Dacryocystorhinostomy failure: association with nasolacrimal silicone intubation. Ophthalmic Surg. 1989 Jul;20(7): 486-9.

18. Reifler DM. Results of endoscopic KTP laser-assisted dacryocystorhinostomy. Ophthal Plast Reconstr Surg. 1993 Dec;9(4):231-6. 